\title{
Modelling the performance of the beef cow to build a herd functioning simulator
}

\author{
Jacques AGABRIEL ${ }^{\mathrm{a} *}$, Stéphane INGRAND ${ }^{\mathrm{b}}$ \\ ${ }^{a}$ INRA, Unité de Recherches sur les Herbivores, Theix, 63122 Saint-Genès-Champanelle, France \\ b INRA, Unité de Recherches sur les Transformations des Systèmes d'Élevage, Theix, \\ 63122 Saint-Genès-Champanelle, France
}

(Received 10 April 2003; accepted 6 September 2004)

\begin{abstract}
This review deals with the representation of the individual animal in herd scale models for cattle. One main problem in these models is to connect two levels of complexity: herd functioning at the farm level and functioning of the individual animal when physiological processes are considered. The text deals first with the representation of the animal and its physiological functions within existing models. Different physiological functions (i.e., growth, intake, lactation and breeding) are rarely modelled in a mechanistic way when used at the herd level, but mostly on an empirical basis, according to classic mathematical laws. The breeding function is the most important one (since it allows for herd renewal) and is frequently modelled as a stochastic process. The body condition score is a relevant indicator of the cow's status, which requires a better representation in individual-based models. Some herd models are presented and discussed and some proposals are presented for a herd functioning model for beef cattle taking into account both animal performance and decisional processes.
\end{abstract}

\section{cattle / herds / cow model / herd models}

Résumé - Modéliser la performance de la vache dans un simulateur de fonctionnement de troupeau allaitant. Cette revue rassemble les différentes manières d'envisager la représentation de l'animal au sein des modèles de simulation de troupeau. Un des problèmes majeurs est en effet de bien faire correspondre deux niveaux de complexité potentielle : celle du fonctionnement du troupeau au sein de l'exploitation agricole, et celle du fonctionnement de l'animal selon la finesse de description des mécanismes biologiques. Ce texte envisage d'abord la manière dont l'animal et ses différentes fonctions physiologiques sont prises en compte dans les modèles existants. Les fonctions de l'animal (croissance, ingestion, lactation) sont rarement modélisées de façon mécaniste, mais plutôt sur la base d'ajustements empiriques selon des lois mathématiques classiques. La reproduction a une place prépondérante car elle gère la dynamique du troupeau simulé. Elle se modélise le plus souvent de façon stochastique. La note d'état est un indicateur fiable des performances individuelles de la vache qu'il faudrait bien savoir représenter pour développer de meilleurs modèles individuels. Ensuite, les modèles développés à l'échelle du troupeau sont présentés et discutés, pour au final, formuler des propositions pour le développement d'un simulateur individu centré intégrant la modélisation du fonctionnement de l'animal en relation avec les décisions de l'éleveur.

\section{bovins allaitants / troupeaux / modèle vache / modèle troupeau}

\footnotetext{
* Corresponding author: aga@clermont.inra.fr
} 


\section{INTRODUCTION}

The evolution of beef cattle farming systems in France can be briefly summarised by an increase in herd size and an increase in production towards the quality sign market. This trend comes with changes in technical management practices, which also depend on economic factors, such as reducing the amounts of input, sales opportunities and/or meat prices throughout the year. Confronted with frequent and unpredictable changes in the production environment, there is a need for farmers and farm advisers to simulate the effects of different production strategies over time (i.e., what to produce? how much? when?).

Considering the complexity of the interactions between decisions of the farmer and the response of the animal (at individual and herd levels) involves the use of computer models. The main objective of these models is to simulate the consequences of different herd management strategies on beef production (categories of animal and weight) using different time scales [28, 43, 44, 49, 50]. In addition, these models may include the economic efficiency of the enterprise.

The objective of this paper is to review the choices that are made to model the individual animal in a herd model simulator. We will focus on the two following questions: what is needed to build a beef herd simulator? What is the place of the individual animal in such a model?

In reviewing the different views on the importance of the individual animal in herd simulators, we also explore the modes of expression of management rules and decisions, and the consequences of translating biological functions at the animal level into herd indicators that are required for feedback processes. This implies choosing the accurate biological level of description.

Apart from using information from existing models, our on-going experience in building a herd functioning simulator [22] will be used to illustrate the problems that were encountered.

\section{MODELS OF PHYSIOLOGICAL FUNCTIONS WITHIN A MULTI-AGENT SIMULATOR}

The main problem of the animal submodel in a herd simulator is to decide on the type of representation of physiological functions and their interactions. It is practically impossible to include all biological processes (e.g. animal biology and herd dynamics operate at different time scales), and a very comprehensive scheme does not guarantee accurate results. It is a challenge to choose an appropriate representation of animal biology that is required and useful with the objective of building the herd simulator.

Physiological functions of cows have been modelled dynamically in the past using different levels and time scales (e.g. for modelling intake [19], digestion and metabolism $[3,13,27]$, reproduction [5] or growth [18, 20]). In herd models, not all of these mechanisms are required. For example, when the objective is to evaluate the relevance of beef cattle management strategies (e.g. Fig. 1), the animal modules should focus on reproduction and growth, and these functions may simply be linked to the average level of production. However, when the objective is also to simulate the effect of energy intake at the herd's scale, the available energy should be divided between different types of animals and quantitative responses of physiological functions (relative to energy intake) are needed. This paper will not review all the potential schemes for each function but will focus on the main types observed in the literature, especially for beef production models.

\subsection{Intake and nutrient utilisation}

The energy available for the animal is determined by intake, which induces the regulation of the physiological processes. Although this scheme is possible, intake and its regulation are usually not taken into account in the animal model of a herd simulator, and rations are determined by the environment. Levels of daily dry matter or 


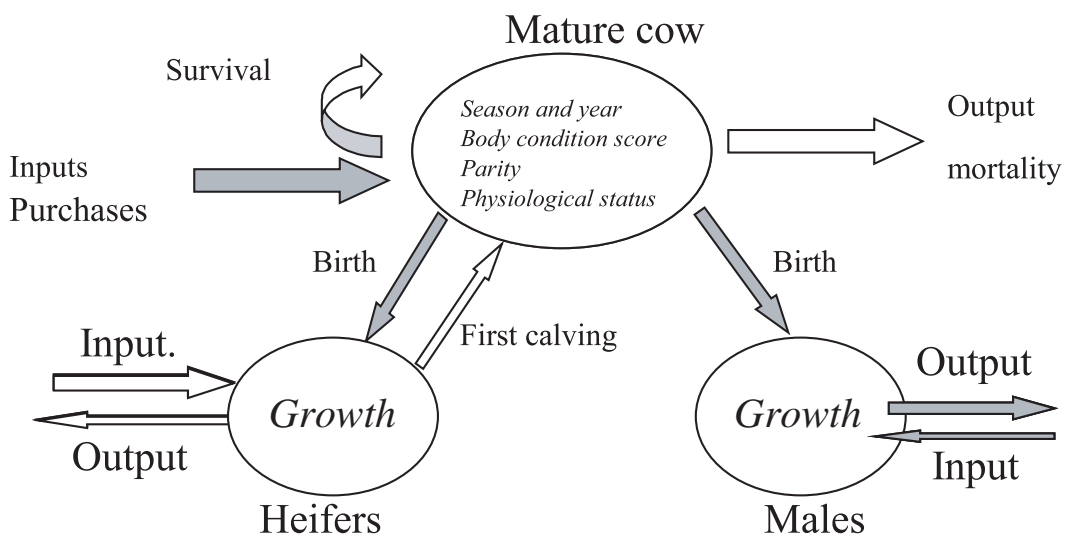

Figure 1. Relationships between the three main groups of animals in the beef herd scale model proposed by Ezanno [16].

average energy supplies given to the animals are fixed for different periods within the year. The production level (pregnancy, lactation, growth) is directly linked to the available energy. In these cases, the average intake of an animal can be estimated by polynomial equations. For example, in Naazie et al. [28] and Sanders et al. [43], intake is determined by NRC equations depending on live weight (LW) and production.

Other authors use intake systems that are applied in a local context, such as the Danish "bulk system" or the French "fill unit system" [23, 24]. In both approaches, a bulk content parameter is associated to each feedstuff and each cow has a bulk intake capacity described by deterministic equations [48]. These systems are easy to use and have been proven useful during the winter period when diets include a large number of fibrous feedstuffs. For beef cattle production systems based on grazing, the feed intake system needs to be adapted for grass intake.

Sauvant [45] proposed a systems approach to animal nutrition, defining two scales of regulation: a short-term "homeostatic" regulation and a long-term "homeorhetic" regulation. This kind of concept is not considered in beef cow models but could be useful to express the animal's abil- ity to balance maintenance and production requirements when nutritional supplies vary over longer periods of time (several weeks).

Including a regulation process of feed intake for individual animals in a herd model could be of interest in situations where intake or feed quality is a tool or a constraint that involves management strategies. For example, animals may receive low energy diets ad libitum for economic purposes during the winter. Intake will then vary during that period affecting milk production and the use of body reserves. The same may occur during the grazing period, when animals adjust their grass intake to the environment and to grass quality. Grazing dynamics are the result of complex interactions between animals and sward characteristics. A few attempts have been made to develop grass intake models, the "Grazplan" model [19] being one of them. However, none of these include a mechanistic model of intake, such as proposed by Baumont [4] where intake is defined at a short time scale and integrates bite prehension as an elementary event of the grazing process. This is linked to a global control of intake quantities depending on the animal physiological status, as proposed by the initial scheme of Sauvant [45]. 


\subsection{Growth and development}

The animal growth process in herd simulators is mostly described by empirical models where parameters are estimated by statistical adjustment. A list of nonlinear functions for describing growth was proposed by Perotto et al. [37] and France et al. [18]. The main conclusion was that the best description of a growth curve over a long period of time is obtained using the Richards function. This function considers two main parameters, as in Brody's model [7], indicating adult body weight and an estimator of maturity (time to assess the adult weight, which may vary with the breed). Brody's model is most commonly used to estimate continuous growth rate. The degree of maturity according to the breed is thus directly accessible (coefficient "a" in the following equation: $\mathrm{BW}=\operatorname{AdultBW}(1-$ $\exp (-\mathrm{at})))$. This quite simple relation is most of the time sufficient to simulate an average growth rate within a given nutritional environment, but not when individual growth has to be assessed for different commercial categories among the whole herd and/or when the nutritional environment varies (e.g. amount and quality of forage in the barn at the beginning of winter). In that case, more mechanistic models of growth should be used [e.g. 20, 26, 31, 51]. Individual-based simulators and/or multi-agent simulators could potentially include these models, but this is actually not yet the case.

\subsection{Lactation and milk yield}

The most well-known and mostly used model is the one by Wood [53], in which milk production (y) depends on the stage of lactation (n) together with 3 parameters a, $\mathrm{b}$ and $\mathrm{c}: \mathrm{y}=\mathrm{a} \mathrm{n} \mathrm{exp}^{-\mathrm{cn}}$. Previous reviews and papers have discussed the interest of this model [25], which appears to be a very simple but robust one. Nevertheless, the parameters do not have a real physiological meaning and the model thus uses a rather empirical approach to lactation. It can also be used for adjusting the production of dif- ferent beef breeds [25]. Another non-linear mathematical expression was proposed by Perochon et al. [35] to adjust dairy cow milk production curves. In addition to Wood, it takes into account factors such as the calving date, insemination, and parity. This could be useful for adjusting beef cow milk production, which is lower than in dairy breeds.

Modelling the relationships between milk yield and energy intake is not yet solved for beef cows. However, beef cows first use their body reserves before reducing their production level if there is a decrease in energy supply [34]. Consequently, at the herd scale, it is not unrealistic to consider a constant milk yield curve irrespective of the nutritional context of the cow and varying only with breed and parity.

\subsection{Energy utilisation and storage; body condition score}

When a whole-cow model is considered, the metabolisable energy from feeds is linked to production and maintenance energy expenditure. The model of Bruce et al. [8] is an example in which main fluxes of energy are taken into account (maintenance, pregnancy, lactation and body reserves), intake being considered as a fixed input. The energy balance is expressed as $\mathrm{I}=\mathrm{C}+\mathrm{B}+\mathrm{M}+\mathrm{Q}$ where I, C, B, M, and Q are respectively energy input, energy retained as conceptus, energy retained in body reserves, energy exported in milk and heat production. Maintenance requirements and energy used for production (i.e., conceptus growth and milk production) are subtracted from the energy supply and the remainder is used for body reserves, which are mainly composed of lipids for an adult cow. Fluxes are calculated on a daily basis. When the calculated remaining energy is negative, a deterministic rule is proposed to spread its effects between milk production and maternal body changes. They are reduced by equal amounts of metabolisable energy below each potential, i.e. lactation and growth. This kind of model was successfully used in different contexts by Sinclair et al. [47]. The same rule between 


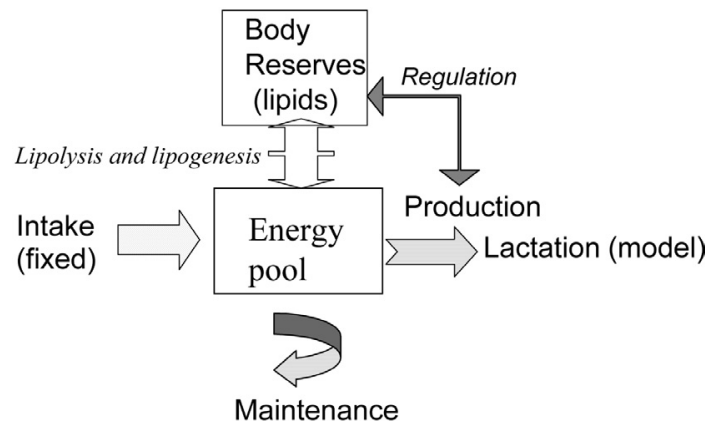

Figure 2. A global scheme for energy flux in the dairy cow model proposed by Roguet and Faverdin [39].

weight changes, variation in lactation and energy supply was used by Sorensen [48] in the "Simherd" model, but the parameters depended on the lactation stage. On the contrary, Plaizier [38] considered this an unnecessary complication when adapting the "Simherd" model to the Ontario context.

Alternatively, a dynamic approach to cow production is possible, as illustrated by the dairy cow model proposed by Roguet and Faverdin [39] (Fig. 2). The available energy is partitioned between maintenance, milk and body reserves. In order to calculate this partitioning, an intermediary pool of energy was considered. Milk synthesis and fluxes of lipids are determined by the amount of available energy in this pool whose variations are described daily. The input flux of energy is represented as a "push" approach. This model focuses on the link between available energy (equilibrium between intake and body reserves) and milk production and is well adapted to dairy production. This scheme could also be of interest when the energy input varies, as for beef cows. Simulated variations of body reserves can be modulated by intake flux and the scheme of relationships between nutrition and production is complete.

It is then possible to build a model of interaction between body reserves and reproduction variables, such as days open or fertility, in order to modify pregnancy rate.
Estimation of the composition of body reserves and variations is an important point when developing energy utilisation models. Models estimate the energy of body mass variations from variation in protein and lipid mass considering the gross energy values $\left(24.2 \mathrm{~kJ} \cdot \mathrm{g}^{-1}\right.$ and $\left.39.3 \mathrm{~kJ} \cdot \mathrm{g}^{-1}\right)$ and energetic efficiencies both for growing and adult animals [52]. For an adult animal in normal conditions, lipids are the only component considered for mobilisation. This simplification is relevant since proteins account for only $15 \%$ of the body mass variation in very lean cows [2].

The link between body reserves and the decision model is generally assessed with the body condition score (BCS). Several BCS scales are used that are determined by slaughter techniques [1,54]. BCS is a parameter that summarises the global status of the beef cow and which can be considered both as a valuable indicator of performance and management. It is a key for modelling beef cow performance. In France, the pregnancy rate of herds is generally high and little variable. The strategy for beef cow stockbreeders is therefore more to minimise inputs than to maximise outputs. The main challenge is to feed the herd at the lowest cost, especially during the winter. The BCS is used for this purpose and nutritional allowances are used to control its variation. Existing herd simulators calculate BCS as a result of nutrition 
given to groups of animals. Although minimal BCS of cows is rarely a target to simulate management strategies, it is a main request of DSS users and could be a challenge for further research.

\subsection{Breeding simulation: mechanical or stochastic approach}

In a herd model, the conception rate of the herd is the ultimate variable to predict, but the way to calculate it differs between authors. As underlined by Denham et al. [12], "The reproduction events (mainly parturition and conception) may be treated as discrete when considering individual animals or as continuous when considering the herd as a whole". This dichotomy is found in all reproduction models developed. A recent review of models that help optimise the management of reproductive animals [6] indicates that differences in definitions originate from the approach taken (i.e., the level of mechanism and the inclusion of stochastic events). Some models $[30,38]$ simulate each individual cow and break down the physiological process into various time scales, while others $[28,43]$ calculate the conception rate stochastically for the whole herd. Factors known to influence the reproduction results can be taken into account in both methods at each level but the predictive values of the models are different.

The "Tamu" model $[43,44]$ uses a global variable calculated for groups of cows: the occurrence of cows in oestrus (fertility) and the conception rate for each oestrus (fecundity). Fertility is estimated in a deterministic way using weight variations of the cows, which depend on their overall nutritional status. The Tess and Kolstad model [49, 50] simplified the process and determined individual post-partum anoestrus (PPAI) with a simplified function: average PPAI varies with genotype and is modified by individual variation of body condition and live weight. Both models do not take into account that some variables are stochastic at the herd level, such as the duration of postpartum anoestrus, the sexual cycle or pregnancy. Their influence on the interval between two calvings can be assessed by using a probability law, as proposed by Blanc et al. [5].

The conception rate of an individual cow may be defined directly by a probability law. A "conception liability index" [42] helps for calculation and depends on the main known factors of influence: cow development (percentage of mature weight), nutritional status (variation of LW) and previous dystocia. This index is calculated in a deterministic way by linear regression.

In the model proposed by Oltenacu et al. [30] (Fig. 3), the breeding process is described for each cow as a sequence of successive events (i.e., calving, cyclicity, mating), which induces a change in physiological status (anoestrus $\rightarrow$ cyclicity $\rightarrow$ pregnancy). The evaluation of herd performance is assessed by the summation of the individuals, allowing to calculate the intervals between (i) calving and first ovulation, (ii) calving and fecundation, (iii) one calving and the next calving, rate of reproduction failure (conception failure and abortion). The transfer from one stage to another is driven by stochastic processes that may be influenced by the animal (breed, parity, nutritional status), management (feeding level). Because of its structure, this model is very adaptable and allows modifying the laws governing each event (e.g. Plaizier et al. [38] modified the law dealing with the end of the anoestrus period). The interest of this model is also that it enables each stage to be assessed in the construction of the interval between calving. Only few performance data are needed to adjust the model parameters and no particular knowledge of the physiological status of the cows is required. Alternatively, a more mechanistic approach may be considered (i.e., more hierarchical by definition). This is the case for the combined effects of body condition score and mating date on the anoestrus duration after calving, used by Blanc et al. [5]. Although these authors consider only a simple interaction between both factors and parity, a complete 


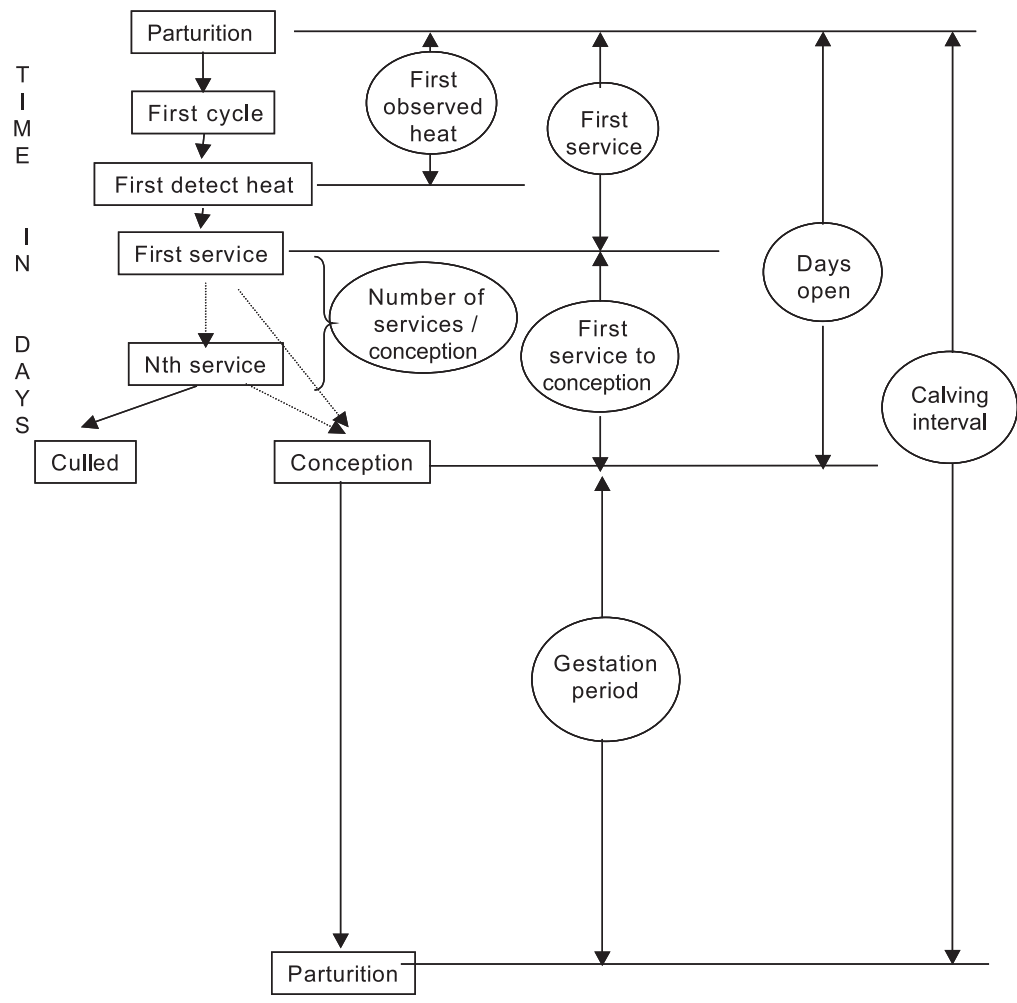

Figure 3. Schematic diagram of the measurements of the reproductive performance of a dairy cow used in the dynamic stochastic model proposed by Oltenacu et al. [30].

mechanistic approach should take into account the seven different factors they mentioned. This explains the difficulties in developing such quantitative models in the near future.

In conclusion, it appears that models describing breeding processes always contain some element of stochasticity, partly because of a lack of knowledge concerning the underlying phenomena. Moreover, some biological events (e.g. fecundation and embryonic fixation) are stochastic by nature. Stochastic models can be used to predict the average herd performance with different management strategies, since stochastic responses concern individuals but could disappear when adding all of them at the herd scale [6]. To quote these authors, "Reproductive performance has complex determinants rely- ing as it does on interacting physiological processes, modulated by changes in environment or alternatives in management: this makes it the ideal subject for modelling".

\section{DISCUSSION/PERSPECTIVES: MODELLING AT THE HERD LEVEL INCLUDING DECISIONAL PROCESSES}

\subsection{Management rules and animal response}

Management rules that are applied over a long time period (i.e., strategic orientation of the production system) have to take into account (i) choice of breed, (ii) calving season and culling decisions, (iii) sorting and 
rearing modalities for all animals produced (type, weight and conformation), (iv) nutritional supplies during the winter. Simulation of herd functioning can then be realised by simulating the dynamics of breeding females expressed for example by the evolution of the herd's demographic structure over time. The simulated outputs depend on the herd structure (i.e., breed and category of animals) and on the response curves of the animals to factors of variation (e.g. nutrition, management). The precision of the outputs is the result of how the "herd system" is considered and modelled, how the animal is represented in this system and how the relationships between these two scales are managed. More importantly, the desired level of precision should be a function of the problems that the simulator is intended to solve, and depends on the expectations of the final user identified at the beginning of the modelling process (i.e., researchers, advisers and farmers).

Modelling decisional processes have mostly been applied in crop production, resulting in the development of decision support systems (DSS) [29]. For example, eight DSS were described in a special issue of Agricultural Systems in 2002 (volume 74). Despite the fact that decision support systems are currently available for end-users, their use has not increased with computer ownership, on the contrary to expectations, as explained by McCown et al. [29]. The main reasons are on the one hand the lack of consideration of questions of potential users and on the other hand the incapacity of available models to answer these questions. However, these types of tools can be considered as more and more useful and essential, not only for research but also for stakeholders such as advisers and farmers, who have to deal with a more and more complex problem in a quickly changing context. In animal production, DSS have been developed (e.g. "Grazplan" [14] or "Sepatou" [10]) to model the grazing process, linking a growth model for grass growth to decisional rules according to grazing and harvesting strategies. Little work has been published concerning the technico-economic aspects of beef production at the herd level. An often referenced DSS is the "Tamu" model $[43,44]$, which describes the herd dynamics by the evolution of classes of representative animals: each class represents an average animal (e.g. heifers for sale, heifers for replacement). A sub model, simulating animal performance, calculates the energy expenditure for maintenance, growth and production (depending on the physiological age) and compares this energy requirement with the available energy resources. This approach is particularly suitable for simulating rangeland systems. For example, the "Tamu" model is used to simulate production of cattle differing widely in genotype for mature size and milk yield within two environments (availability of forages) or to simulate cattle production under spring and fall calving systems.

More recently, Tess and Kolstad [49, 50] developed a herd management model to compare herds of different genotypes in their adaptation capacity over a long-term period. This approach is based on using empirical models of evolution of biological functions of cows and growing cattle; an approach also used for modelling dairy farming systems [41]. Management rules were not explicitly specified. The model simulates life cycle weight and body composition changes for different genotypes in the same environment, changes in forage quality or changes in cow nutrition around calving, but also the response in enterprise efficiency for different genotype systems including input, costs and sales. The originality of such a model consists in the consideration of the complete life cycle of the cow and its ability to produce differently over time, in interaction with management decisions (e.g. forage quality or nutrition around calving). Decisions concerning genetics, which are generally the main purpose for developing such a type of a model, were simulated through modifications in animal responses. No logical chain of decisions concerning different production projects were taken into account. 
Table I. Examples of objectives and structures for different beef cattle herd models.

\begin{tabular}{|c|c|c|c|}
\hline Authors & Model objectives & Model Structure & Animal types \\
\hline $\begin{array}{l}\text { Sanders and } \\
\text { Cartwright (1979) } \\
{[43,44]}\end{array}$ & $\begin{array}{l}\text { Simulate production per- } \\
\text { formance in various nutri- } \\
\text { tional environments with } \\
\text { cattle differing in genotypes }\end{array}$ & $\begin{array}{c}\text { Deterministic } \\
\text { Submodels for herd dynamics } \\
\text { and animal performance } \\
\text { (growth, fertility, culling) }\end{array}$ & $\begin{array}{l}\text { Average animal } \\
\text { within chosen class } \\
\text { (heifers, cows) }\end{array}$ \\
\hline $\begin{array}{l}\text { Pang et al (1999) } \\
{[32,33]}\end{array}$ & $\begin{array}{l}\text { Effects of production traits } \\
\text { and management strategies } \\
\text { on bio-economic efficiency } \\
\text { of beef production system }\end{array}$ & $\begin{array}{c}\text { Dynamic, deterministic } \\
4 \text { parts: herd inventory, } \\
\text { nutrient requirements, forage } \\
\text { production, economic }\end{array}$ & $\begin{array}{l}\text { Representative } \\
\text { groups }\end{array}$ \\
\hline $\begin{array}{l}\text { Tess and Kolstad } \\
(2000) \\
{[49,50]}\end{array}$ & $\begin{array}{c}\text { Model of range beef cattle } \\
\text { production: comparison of } \\
\text { genetic types } \\
\text { economic performances }\end{array}$ & $\begin{array}{c}\text { Management variable } \\
\text { assigned by user } \\
\text { Individual performance } \\
\text { is simulated (growth lactation, } \\
\text { reproduction...) }\end{array}$ & $\begin{array}{l}\text { Individual animals } \\
\text { are simulated over } \\
\text { complete life cycle }\end{array}$ \\
\hline $\begin{array}{l}\text { Ezanno (2002) } \\
{[16]}\end{array}$ & $\begin{array}{c}\text { Model of bovine herd } \\
\text { productivity in a tropical } \\
\text { environment Effects of dam } \\
\text { body reserves }\end{array}$ & Stochastic & $\begin{array}{l}3 \text { classes: males, } \\
\text { growing females, } \\
\text { growing cows } \\
\text { producing }\end{array}$ \\
\hline $\begin{array}{l}\text { Naazie et al (1996) } \\
\text { [28] }\end{array}$ & $\begin{array}{l}\text { Model of beef } \\
\text { production efficiency }\end{array}$ & $\begin{array}{c}\text { Deterministic and stochastic } \\
3 \text { submodels (growth and feed } \\
\text { intake, herd, enterprise efficiency) }\end{array}$ & $\begin{array}{l}\text { Classes of animals by } \\
\text { age (determined by } \\
\text { sex and breeding) }\end{array}$ \\
\hline
\end{tabular}

On the contrary, some models optimise or simulate the effect of management rules on suckler cattle or sheep production. Recently, Romera et al. [40] developed a simulator that gives the user the opportunity to specify decisions rules, representing different management options. Other approaches included a specific representation of a production strategy related to the position of simulated events (breeding, feeding) in the calendar [11].

In a model developed to simulate the reproductive behaviour of ewes at the flock level, Cournut [9] included the decisional module as a separate process. This model is based on breeding management rules and describes specific groups of females within the herd according to lambing season, each group being managed in the same way. The effect of different breeding management rules are assessed from group responses, which are obtained by simulating each animal in the herd, as in individual based models [36].

\subsection{Simulating batches and careers, reconstituting performance level and variability}

As mentioned previously, the degree of complexity of the model is defined according to its objectives. A recent review [9] illustrates possible objectives for simulating animal performance and the corresponding choice of model structure. Some examples are given in Table I for different types of models, being either stochastic or deterministic, mechanistic or empirical. Two different approaches were taken, either based on a descriptive representation of homogeneous groups, or a more ambitious process using individual-based modelling [17, 36 , 48]. In the first approach, herd dynamics is the result of the dynamics of each subclass of animals. The variability of performance is assessed by the variance for each group. This approach was developed for beef cattle herds by Sander and Cartwright [43] and 
Ezanno [16]. Firstly, a decision has to be made to divide the herd into homogeneous sub-units. This may be based on age or physiological needs or also management considerations (e.g. feeding, breeding). Rotz et al. [41] defined six classes of animals to simulate dairy herd dynamics: early, mid, late and non-lactating cows, old and young heifers. Individuals go from one class to another according to decisional rules. At any point in time, a class is described by the average animal. When the objective of the model is to test the effects of different nutritional supplies (e.g. [43, 44]), requirements are defined for each group and food supply is adjusted accordingly. The emergence of a herd-scale specific behaviour is then determined by the evolution of average animals in each group, defining career patterns.

In the second approach, herd dynamics is derived from a variation in the number of animals due to reproduction and culling events (e.g. [48]). Each animal is modelled as a separate entity having its own characteristics. These characteristics represent the main biological functions and have to be ranked to express a realistic variability. The individual-based approach to modelling herd dynamics is more recent and is made possible by the evolution in computing performance. Herd performance is assessed by summarising all individual animals. The evolution of each animal is either driven by its physiological status. At any time, all individual characteristics are available (e.g. age, physiological status, weight). The explicit representation of each animal within the herd makes it possible to be more realistic and specific, especially for beef cattle where management and economic decisions are individual-based (compared to sheep flock management). This also allows conditional management rules to be applied to each individual (e.g. selling animals in a batch according to a threshold weight). The limitation of this approach is the lack of knowledge about interactions between animals managed together within a batch, and the effects on physiological functions (e.g. feeding, breeding). Only a few "group factors" influencing the anoestrus duration of cows have been included in mechanistic models (e.g. feeding level in relation with competition at trough, presence of the bull, season) [5].

The evolution of individual-based models towards multi-agent models can also be useful to simulate herd dynamics [36]. The challenge is to assess information to simulate interactions between animals within the herd, such as in the model developed by Dumont and Hill [15] for grazing sheep. Each sheep has its own social behaviour (making choices between activities such as grazing, drinking, and moving) associated to a specific memory capacity. The group behaviour (especially the spatial behaviour within the paddock) can then not be described simply by summation of individual statistics. Concerning feeding behaviour during the winter, there are also some interactions among animals in the same group (due to the configuration of the feeding area, and linked to social ranking), but knowledge is still insufficient to take these into account in the models. Some studies (e.g. [21]) have been conducted to understand how the group composition of beef cows influences feeding behaviour and feed intake according to physiological status and feeding conditions (e.g. feed offer, competition at the trough). For example, dry cows eat more than they need when mixed with lactating counterparts in the same group [21]. Without competition, physiological state appears to be the first factor determining intake, but with competition the social rank of the cow is more important.

\subsection{Proposals for a simulator of herd functioning used as a DSS}

One question evoked by Sanders and Cartwright about simulators [43] in 1979 is "what should be done with the simulation results?". They observed that simulation results can increase knowledge concerning livestock production but cannot give an adequate basis for decisions by producers. Of course, this question is still of interest 


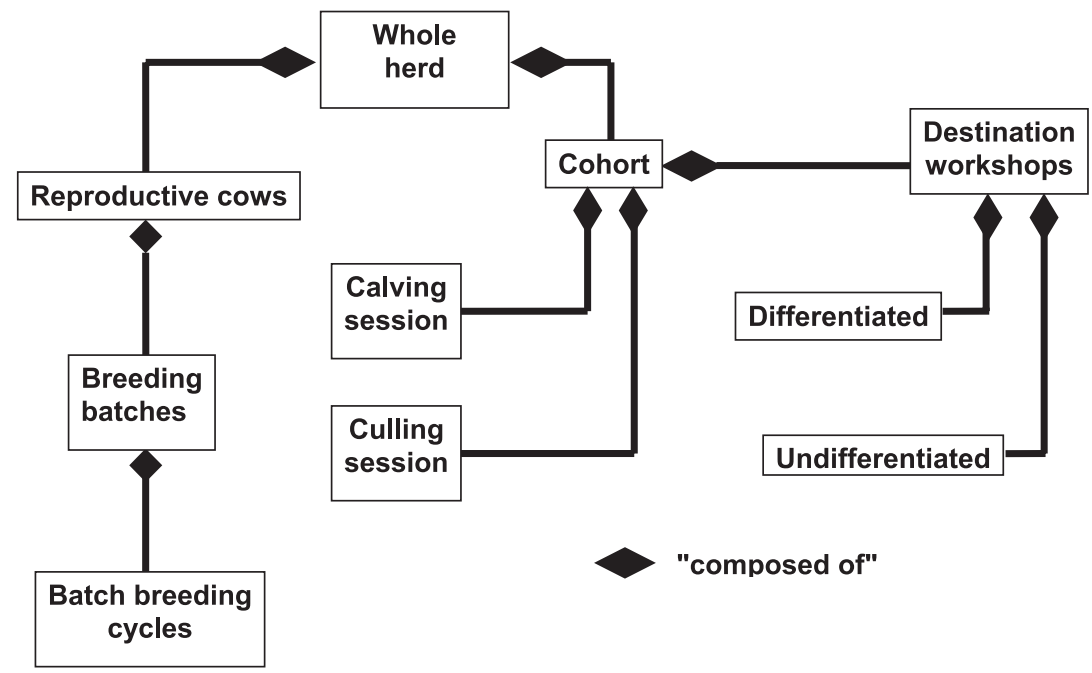

Figure 4. Collective management entities at the herd level. A breeding batch involves cows calving at a specific season in a year. A cohort concerns either calves or culled cows, issued respectively from a specific calving and culling session. Workshops contain animals either already sorted for a specific destination (selling or replacement) or not yet sorted (undifferentiated).

even if the current generation of models is scientifically more sound than those developed in the past. Tess and Kolstad [49] specified that models are tools and should be designed for specific purposes: they do not think that a general model can be developed to study all cases of beef production.

Our proposals are now to draw guidelines to build a dynamic model to predict the cow/calf system for a given pattern of the breeding system (i.e. with outputs focused on the number and characteristics of animals produced, as well as the time of selling in the year). Our initial objective was to develop a model by and for researchers, which eventually could become a decision support system for extension agents to discuss with farmers possible directions of the production system [46].

\subsubsection{Modelling technique}

The multi-agent modelling process should be chosen because it focuses on interactions between elementary components of the system. Two kinds of agents can be considered: the animals and the farmer. The goal was to consider each animal within the herd separately and to describe it at any time during the simulation process. The farmer agent will interact with his animals through decision rules. He takes decisions by evaluating animal performance. Time can be managed using the discrete-time simulation technique. The actions and state changes in the system are considered as calendar events (e.g. fecundation, calving, weaning). To represent the occurrence of such events, the minimal time step is one day.

\subsubsection{Management entities}

The link between biological and decisional models can be assessed by describing entities representing decisional units in the herd management process (Fig. 4). These virtual entities are useful to build the conceptual model and can be described using 
expertise and farm observations. The characterisation of these entities, as the description of their coordination over time, allows specifying the farmer's livestock production organisation. The decisional sub-model is a set of rules that have to take into account the different farmer's projects according to the expected level of animal performance.

\subsubsection{Breeding and culling}

The evolution of calving distribution in a herd over a long-term period is the first output expected from such a simulator. The breeding process is the first complete physiological function that should be modelled in the simulator, including the stochastic phenomena (e.g. anoestrus duration), using an individual-based approach. The beginning and ending days of the breeding period are parameters that define breeding entities. Voluntary culling can be defined by specific rules [40]. Each culling session occurs depending on the farmer's decision. The culling criteria for these sessions could be age and reproductive failures (no fecundation, abortion, calf's death during the first month after birth). Involuntary culling (mortality, accidents) may be fixed (2 to 5\% of the whole herd) depending on the environment.

\subsubsection{Cow feeding management}

Feeding management can be quantitatively or qualitatively described, the latter choice being the easiest. A quantitative approach of food supply is needed only if proportional responses are expected. It is important to consider the main objectives (i.e. the outputs) of the simulator before choosing a complex quantitative approach. A description of different BCS patterns at different key events could be sufficient. It is for example a good option if the model can simulate the impact of management on environmental parameters (e.g. grazing management and biodiversity in the pasture).

The next objective was to link feeding and rations with the availability of forage and concentrates on the farm, and to consider different qualities of diet components together with different categories of animals to feed.

\subsubsection{First validation}

This could correspond to a control of the outputs after connecting the different biological sub-models. Culling rate, calving distribution according to nutritional levels and body condition patterns should fit the data obtained in experimental farms or from surveys carried out on private farms. Several tests could be performed to check the values generated when performing stochastic procedures such as calving modalities, or abortion rates.

\section{CONCLUSION}

Most of the herd scale simulators are built to handle at least a limited number of strategic decisions, dealing for example with feeding management, and culling policy (i.e., decisions that do not change within the production year or production cycle). These simulators are often less informative about individual animals within the herd. Very few simulators deal with tactical decisions (i.e., on a short-term period), which occur as a response to the system performance (feedback within the model). For example, in most models culling policy does not vary with the global performance of the herd. This aspect is linked with the compromise that has to be made between two opposite trends when models become decision support systems: (i) the researcher's willingness to describe more and more precisely the phenomenon in a process in order to understand the true driving forces. This generally results in the development of a mechanistic approach: (ii) the DSS's user wishes to use a simple tool based on parameters easily accessible on a private farm. This probably means that a particular effort is needed to satisfy both trends. One example concerns the link we made between the 
BCS and breeding performance of the cow. For most researchers, the BCS is probably not considered as the main force controlling breeding performance and would not be considered as a physiological state. Nevertheless, it is a trait easily accessible for farmers, and is an indicator for feeding, breeding, and culling decisions. The divergence between modelling for increasing the knowledge and modelling for helping decision-making should be taken into consideration and will most likely lead to two different tools. A final aspect for DSS development is the necessity to involve end users in the process, a remark more easily said than done.

\section{REFERENCES}

[1] Agabriel J., Giraud J.M., Petit M., Détermination et utilisation de la note d'état d'engraissement en élevage allaitant, Bull. Tech. CRZV Theix 66 (1986) 43-50.

[2] Agabriel J., Petit M., Recommandations alimentaires pour les vaches allaitantes, Bull. Tech. CRZV Theix 70 (1987) 153-166.

[3] Baldwin R.L., France J., Beever D.E., Gill M., Thornley J.H.M., Metabolism of the lactating cow. III. Properties of mechanistic models suitable for evaluation of energetic relationships and factors involved in the partition of nutrients, J. Dairy Res. 54 (1987) 133-145.

[4] Baumont R., Cohen-Salmon D., Prache S., Sauvant D., A mechanistic model of intake and grazing behaviour in sheep integrating sward architecture and animal decisions, Anim. Feed Sci. Technol. 112 (2004) 5-28.

[5] Blanc F., Blanc J., Dozias D., Agabriel J., Modélisation de l'efficacité de la reproduction chez la vache allaitante. Effet de la date d'introduction du taureau et de l'état d'engraissement à vêlage sur l'intervalle vêlage-saillie fécondante, Renc. Rech. Rumin. 9 (2002) 65.

[6] Blanc F., Martin G., Bocquier F., Modelling reproduction in farm animals: a review, Reprod. Fert. Develop. (2001) 337-353.

[7] Brody S., Plane of nutrition, the principle of diminishing increments, and efficiency, in: Brody S. (Ed.), Bioenergetics and growth, Reinhold Publ Co. (1945) reprinted by Hafner Publishing Co., New York, USA, 1964, pp. 76-99.

[8] Bruce J.M., Broadbent P.J., Tops J.H., A model of the energy system of lactating and pregnant cows, Anim. Prod. 38 (1984) 351362.

[9] Cournut S., Le fonctionnement des systèmes biologiques pilotés : simulation à événements discrets d'un troupeau ovin conduit en trois agnelages en deux ans, Thèse de doctorat de l'université Claude Bernard, Lyon I, 2001, 418 p. + annexes.

[10] Cros M.J., Duru M., Peyre D., SEPATOU, un simulateur de conduites du pâturage à l'épreuve des menus Bretons, Fourrages 167 (2001) 365383.

[11] Dedieu B., Cournut S., Ingrand S., Perochon L., Agabriel J., Modeling the technical management of livestock production as a combination of functional animal entities, in: Product quality based on local resources and its potential contribution to improved sustainability, 6th International Livestock Farming System Symposium, Benevento, 26/29 August 2003.

[12] Denham S.C., Larsen R.E., Boucher J., Adams E.L., Structure and behavior of a deterministic model of reproductive performance in beef cattle, Agric. Syst. 35 (1991) 21-36.

[13] Dijkstra J., Neal H. D.St.C., Beever D.E., France J., Simulation of Nutrient Digestion, Absorption and Outflow in the Rumen: Model Description, Am. Inst. Nutr. (1992) 22392256.

[14] Donnelly J.R., Freer M., Salmon L., Moore A.D., Simpson R.J., Dove H., Bolger T.P., Evolution of the Grazplan decision support tools and adoption by the grazing industry in temperate Australia, Agric. Syst. 74 (2002) 115-139.

[15] Dumont B., Hill D.R.C., Spatially explicit models of group foraging by herbivores: What can Agent Based Models offer? Anim. Res. 53 (2004) 419-428.

[16] Ezzano P., Modélisation de la relation entre l'état des réserves corporelles et la productivité des troupeaux bovins, cas des bovins N'Dama en milieu agro-pastoral extensif de zone tropicale humide (Kolda, Sénégal), Thèse de doctorat de l'ENSAM, Montpellier, 2002, 56 pages + annexes.

[17] Force C., Pérochon L., Hill D.R.C., Simulation à l'aide d'un modèle individu-centre de l'impact des mammites sur les performances des vaches laitières, in: Faye B., Ingrand S. (Eds.), Modélisation du Fonctionnement des Troupeaux, Cirad-Emvt, 1, 2000, pp. 81-88.

[18] France J., Dijkstra J., Dhanoa M.S., Growth functions and their application in animal science, Ann. Zootech. 45 (Suppl. 1) (1996) 165174. 
[19] Freer M., Moore A.D., Donnelly J.R., GRAZPLAN: Decision Support Systems for Australian Grazing Enterprises-II. The Animal Biology Model for Feed Intake, Production and Reproduction and the Grazfeed DSS, Agric. Syst. 54 (1997) 77-126.

[20] Hoch T., Agabriel J., A mechanistic dynamic model to estimate beef cattle growth and body composition: 1. Model description, Agric. Syst. 81 (2004) 1-15.

[21] Ingrand S., Niveau d'ingestion, comportement alimentaire et performances de vaches Charolaises alimentées en quantités limitées : effet de la composition des groupes, Renc. Rech. Rumin. 10 (2003) 377.

[22] Ingrand S., Dedieu B., Agabriel J., Pérochon L., Modélisation du fonctionnement d'un troupeau bovin allaitant selon la combinaison des règles de conduite. Premiers résultats de la construction du simulateur SIMBALL, Renc. Rech. Rumin. 9 (2002) 61.

[23] INRAtion, Logiciel de rationnement des Ruminants - Vaches allaitantes, in: Agabriel J., Champciaux P., Espinasse C. (Eds.), INRAtion - CNERTA, $26 \mathrm{Bd}$. du docteur Petitjean, 21000 Dijon, France, 1990.

[24] Jarrige R., Demarquilly C., Dulphy J.P., Hoden A., Robelin J., Beranger C., Geay Y., Journet M., Malterre C., Micol D., Petit M., The INRA « fill unit » system for predicting the voluntary intake of forage-based diets in ruminants: a review, J. Anim. Sci. 63 (1986) 1737-1758.

[25] Jenkins T.G., Ferrell C.L., Lactation characteristics of nine breeds of cattle fed various quantities of dietary energy, J. Anim. Sci. 70 (1992) 1652-1660.

[26] Keele J.W., Williams C.B., Bennett G.L., A computer model to predict the effects of level of nutrition on composition of empty body gain in beef cattle: I. Theory and development, J. Anim. Sci. 70 (1992) 841-857.

[27] Lescoat P., Sauvant D., Development of a mechanistic model for rumen digestion validated using the duodenal flux of amino acids, Reprod. Nutr. Dev. 35 (1995) 45-70.

[28] Naazie A., Makarechian M., Hudson R.J., Efficiency of Beef Production Systems: Description and Preliminary Evaluation of a Model, Agric. Syst. 54 (1997) 357-380.

[29] Mc Cown R.L., Hochman Z., Carberry P.S., Probing the enigma of the decision support system for farmers. Learning from experience and from theory, Agric. Syst. 74 (2002) 1-10.
[30] Oltenacu P.A., Milligan R.A., Rousaville T.R., Foote R.H., Modelling reproduction in a herd of dairy cattle, Agric. Syst. (1980) 193-205.

[31] Oltjen J.W., Bywater A.C., Baldwin R.L., Evaluation of a model of beef cattle growth and composition, J. Anim. Sci. 62 (1986) 98108.

[32] Pang H., Makarechian M., Basarab J.A., Berg R.T., Application of a dynamic simulation model on the effects of calving season and weaning age on bioeconomic efficiency, Can. J. Anim. Sci. 79 (1999) 419-424.

[33] Pang H., Makarechian M., Basarab J.A., Berg R.T., Structure of a dynamic simulation model for beef cattle production systems, Can. J. Anim. Sci. 79 (1999) 409-417.

[34] Petit M., Jarrige R., Russel A.J.F., Wright I.A., Feeding and nutrition of the suckler cow, in: Jarrige R., Béranger C. (Eds.), Beef cattle Production, World Anim. Sci., Elsevier Amsterdam, C1, Chap. 9, 1992, pp. 191-208.

[35] Pérochon L., Coulon J.B., Lescourret F., Modelling lactation curves of dairy cows with emphasis on individual variability, Anim. Sci. 63 (1996) 189-200.

[36] Pérochon L., Force C., Hill D.R.C., Coulon J.B., Gasqui P., Simulation à l'aide d'un modèle individu centré de l'impact des mammites sur les performances des vaches laitières, in: Modèles et systèmes multi-agents pour la gestion de l'environnement et des territoires, Actes du colloque Smaget, ClermontFerrand, Cemagref/Engref, 5/8 octobre 1998, pp. 39-50.

[37] Perotto D., Cue R.I., Lee A.J., Comparison of nonlinear functions for describing the growth curve of three genotypes of dairy cattle, J. Anim. Sci. 72 (1992) 773-782.

[38] Plaizier J.C.B., King G.J., Dekkers J.C.M., Lissemore K., Modeling the Relationship between Reproductive Performance and Netrevenue in Dairy Herds, Agric. Syst. 56 (1998) $305-322$.

[39] Roguet C., Faverdin P., Modèle dynamique de la lactation des vaches laitières en fonction des apports énergétiques, Renc. Rech. Rumin. 6 (1999) 156.

[40] Romera, A.J., Morris S.T., Hodgson J., Stirling W.D., Woodward S.J.R., A model for simulating rule-based management of cow-calf systems, Comput. Electron. Agric. 42 (2004) 67-86.

[41] Rotz C.A., Mertens D., Buckmaster D.R., Allen M.S., Harrison J.H., A dairy herd model 
for use in whole farm simulations, J. Dairy Sci. 82 (1999) 2826-2840.

[42] Roughsedge T., Amer P.R., Simm G., A bioeconomic model for the evaluation of breeds and mating systems in beef production enterprises, Anim. Sci. 77 (2003) 403-416.

[43] Sanders J.O., Cartwright T.C., A general cattle production systems model, I: Structure of the model, Agric. Syst. 4 (1979) 217-227.

[44] Sanders J.O., Cartwright T.C., A general cattle production systems model, II: Procedures used for simulating animal performance, Agric. Syst. 4 (1979) 289-309.

[45] Sauvant D., La modélisation systémique en nutrition, Reprod. Nutr. Dev. 32 (1992) 217 230.

[46] Sébillote M., Soler L.G., Les processus de décision des agriculteurs. Acquis et questions vives, in: Brossier J., Vissac B., Le Moigne J. (Eds.), Modélisation systémique et systèmes agraires, Paris, INRA, 1990, pp. 88-102.

[47] Sinclair K.D., Molle G., Revilla R., Roche J.F., Quintans G., San Juan L., Sanz A., Mackey D.R., Diskin M.G., Effects of body condition at calving, post-partum nutrition and calf access on the interval from calving to first ovulation in beef cows: Cow performance and metabolism, BSAS Abstracts, 2000.
[48] Sorensen J.T., Kristensen E.S., Thysen I., A Stochastic Model Simulating the Dairy Herd on a PC, Agric. Syst. 39 (1992) 177-200.

[49] Tess M.W., Kolstad B.W., Simulation of cowcalf production system in a range environment. I. Model development, J. Anim. Sci. 78 (2000) 1159-1169.

[50] Tess M.W., Kolstad B.W., Simulation of cowcalf production system in a range environment. II. Model evaluation, J. Anim. Sci. 78 (2000) 1170-1180

[51] Williams C.B., Jenkins T.G., A computer model to predict composition of empty body weight changes in cattle at all stages of maturity, J. Anim. Sci. 76 (1998) 980-987.

[52] Williams C.B., Jenkins T.G., A dynamic model of metabolizable energy utilisation in growing and mature cattle. II. Metabolizable energy utilisation for gain, J. Anim. Sci. 81 (2003) 1382-1389

[53] Wood P.D.P., Algebric model of the lactation curve in cattle, Nature 216 (1967) 164-165.

[54] Wright I.A., Russel A.J.F., Partition of fat, body composition and body composition score in mature cows, Anim. Prod. 38 (1984) 23-32. 